\title{
EARLY DISCOVERERS
}

\author{
XXI
}

\section{A DESGRIPTION AND EXPLANATION OF GLAGIAL TILL IN I6o3 GEORGE OWEN (I552-I6I3)}

\author{
By B. S. JoHN \\ (Jesus College, Oxford, England)
}

George Owen of Henllys, in Pembrokeshire, was a man of acute observation with a keen interest in the geological and geomorphological features of his home county. Through a section on the limestone and coal outcrops of the county in his Description of Penbrokshire (Owen, r 892) he gained a nineteenth-century reputation as the "patriarch of English geologists" (Anon., I84I, p. 3). Conybeare and Phillips ( 1822 , introduction, p. $x l$ ) believed that his geological observations represented "undoubtedly the earliest attempt to establish the important and fundamental geological fact that the same series of rocks succeed each other in a regular order throughout extensive tracts of country, and to elucidate the geological structure thus indicated".

However, of equal importance and interest is a neglected passage in the same work (Owen, r 892) in which Owen (unpublished) set down what must be one of the most accurate early descriptions of glacial till. Referring to the till as "Claye Marle", he wrote:

"This kind of Marle is digged out of the Earthe where it is found in great quantitie and thought to be in rounde great heapes and lompes of Erthe as bigg as round hills, and is of nature fatt toughe and clamye. . [p. 7r]. This marle is of couler with vs most commonlie blwe and in some place redd... . It is verie hard to digg by reason of the toughness, much like to waxe, and the pickax or mattock beinge stroken into it, is hardlie drawne out againe, so fast is it holden; it is also verie heavie as ledd." [p. $72-73$ ]

Turning his attention to the origin of the marl, Owen was prompted by all his carefully collected evidence to accept the current theory that the drift had been deposited catastrophically by the sea:

"The opinion of the Countrie people where this Marle is founde is that it is the fattnes of the Earthe gathered at Noes flood, when the Erthe was Covered withe the said flood a whole yeare, and the surginge and tossinge of the said flood, the fattnes of the Earthe being clamye \& slymie of nature did gather together, and by rowlinge vpon the Earthe became round in forme, and when the flood departed from the face of the Earthe, the same was left drie in sondrie partes, which is nowe this Marle that is found. and how the Comon people Cam to this opinion I knowe not but it is verye like to be true, for wheresoever the same is founde, it is loppie [loose] and covered with sande gravell and rounde pebblestones such as you shall finde at the sea side verie plaine, appearing that the stones hath ben worne by the sea or some swift river.

"Also in the harte of the Marle is founde diverse sortes of shells, of fishe, as Cogle shells, Muskell shells, and such like, some altogether rotten and some yet unrotted as also you shall therein finde peaces of tymber that ben hewen vith edge tooles \& fire brandes, the one ende burned and diverse other thinges which hath ben before tyme vsed, \& this $\mathrm{XX}^{\text {tie }}$ foote and more deepe in the Earth in places that never haue ben digged before, and over the which great oakes are now growinge: and this seaven or eight myles from the sea so that it is verie probable that the same came into these places at the tyme of the great and generall flood." [p. $\left.7 \mathrm{I}^{-72}\right]$

Owen noted the widespread, intermittent distribution of the till, and wrote further:

"This Marle is founde in Kemes and both Emlyns from Dynas vpp to Penboyr in Carmarthen sheere, beinge about twentie myles in lengthe and fowre myles in bredeth in most places to the sea syde, and out of this compasse I cannot heare that the same ys founde: I think more for want of Industrie then otherwise ..." [p. 73] 
He ended his description of the clay marl with these words:

"... and who so list to learne more of this marle: let him pervse a pamphlett which I have written thereof, wherein I have declared the nature of the marle, how to know yt and finde yt. . And soe for brevyties sake I Cesse here to writte any more thereof." [p. 73]

Henry Owen, who edited and commented on the description when it was re-published in I 892, noted in his preface (p. xxiv) that this "pamphlett" was completed in I 599. It may be found in the Vairdre Book of MSS. at the National Library of Wales, and contains, among other things, details of the origin and characteristics of the marl and information on where the various types of marl may be found.

Thus it seems that as early as I 599 Owen had completed his observations on the clay marl to his own satisfaction. He did not ascribe a glacial origin to the drift, but accepted, in the fashion of the day, that the marl and associated deposits had been laid down by the "great and generall flood". Nevertheless, his work was quite outstanding for its accuracy. His description is such that one has no difficulty in recognizing his "claye marle" as the Irish Sea till which is found in both eastern Ireland and west Wales. He was correct in his observation that the till contains shell and wood fragments, and he also clearly recognized that $i t$ is everywhere characterized by a tough, compact clay matrix. He even noticed the subtle colour difference between the calcareous unweathered blue clay and the weathered and decalcified red clay which overlies it. Significantly, he recognized the till's most important stratigraphic relationship, namely, that it is often overlain by water-deposited sands and gravels.

Jehu (1904), who quoted Owen's work at length in his classic paper on the glacial deposits of north Pembrokeshire, stated that his I 599 pamphlet on the clay marl contained "perhaps the earliest attempt to give a full description of the boulder-clay". Indeed, it may represent the earliest attempt to differentiate on a stratigraphical basis between the "Lower Till" and the "Middle Glacial Sands and Gravels" of Britain, the lower members of a tripartite glacial succession which has excited the attention of British geologists and glaciologists for so many years.

MS. received 26 May 1964

\section{REFERENCES}

Anon. 1841. Article on Sir Roderick Murchison's "Silurian system". Edinburgh Review, Vol. 73, No. 147, p. 1-141. Conybeare, W. D., and Phillips, W. 1822. Outlines of the geology of England and Wales. Pt. 1. London, William Phillips.

Jehu, T. J. I904. The glacial deposits of northern Pembrokeshire. Transactions of the Royal Society of Edinburgh, Vol. 4 I, No. 4 , Pt. I, p. $53-87$.

Owen, G. Unpublished. Treatise on clay marl. [MS., written in 1599; in the Vairdre Book, National Library of Wales.]

Owen, G. 1892. The description of Pembrokeshire [1603], by George Owen of Henllys, Lord of Kemes, edited with notes and appendix by Henry Owen. London, Charles J. Clark. (Cymmrodorion Record Series, No. i.) 